\title{
Fusion-Negative Alveolar Rhabdomyosarcoma
}

National Cancer Institute

\section{Source}

National Cancer Institute. Fusion-Negative Alveolar Rhabdomyosarcoma. NCI

Thesaurus. Code C123732.

An alveolar rhabdomyosarcoma characterized by the absence of chromosomal translocation $\mathrm{t}(1 ; 13)(\mathrm{p} 36 ; \mathrm{q} 14)$ or $\mathrm{t}(2 ; 13)(\mathrm{q} 35 ; \mathrm{q} 14)$ and therefore the absence of PAX7-

FOXO1 or PAX3-FOXO1 gene fusion. 